Review

\title{
Effect of photoperiod on intestinal microbiota and circadian rhythm, and its influence on performance, the immune system and the welfare of broiler chickens
}

Received: November, 2020; Accepted: January, 2021

\author{
Bauer Oliveira e Alvarenga ${ }^{1 *}$, Adrieli Macanhão Biavatti ${ }^{2}$, \\ Antonio J. Piantino Ferreira ${ }^{3}$
}

\begin{abstract}
The intestinal microbiota of broiler chickens still reserves a great amount of secrets and mysteries. However, it is known that it acts directly on the host's health, but that it is also influenced by several factors, among them the light. Due to the importance of the world production of birds, this review of literature had the objective to shelter the most recent studies, which relate the photoperiod and the circadian rhythm, with the intestinal microbiota, the zootechnical performance, the immune system and the welfare of broiler chickens. Describing in a single work the existence of a bilateral relationship between the intestinal microbiota, the immune system and its host, and that can be directly influenced by light management.
\end{abstract}

Keywords: Light program, Eubiosis, Dysbiosis, Intestinal Health, Chickens.

\section{Introduction}

Light is an important exogenous factor for birds, and it is closely related to important physiological functions, such as body temperature regulation, as well as food and digestive processes. Hormonal birds' activities are also related to light, including growth and reproduction (Pittendrigh and Daan, 1976; Walton, Weil, and Nelson, 2011; Pandey, 2019).

\footnotetext{
${ }^{1}$ Faculdade de Medicina Veterinária e Zootecnia da Universidade Federal de São Paulo; Biocamp Laboratórios Ltda.

${ }^{2}$ Coopavel.

${ }^{3}$ Faculdade de Medicina Veterinária e Zootecnia da Universidade Federal de São Paulo.

* Corresponding author: Rua Rui Ildefonso Martins Lisboa, 347, Bairro Campo dos Amarais CampinasSP-Brasil baueralvarenga@biocamp.com.br (Orcid: https://orcid.org/0000-0002-4863-4526)
} 
With the advancement of industrial poultry, increasingly conventional aviaries, in which external factors influence the internal environment, are being replaced by more advanced aviaries, where external factors have little or no effect in the internal conditions, allowing maximum thermal comfort and welfare for the birds. As a consequence, several researches were carried out to study the possible impacts of the transition from natural to artificial light (Olanrewaju et al., 2014; Huth and Archer, 2015; Westland et al., 2017; Tähkämö et al., 2018), as well as the wavelength, light intensity and duration/distribution of the photoperiod (Lewis and Morris, 1998). Therefore, the current industrial poultry has greater control over the lighting of the aviaries, and with that, different circadian rhythms are worked throughout the creation of the poultry, which may influence the zootechnical performance and the welfare of the birds, as well as their intestinal microbiota.

In recent years, much has been debated about possible impacts of light programs on zootechnical performance and animal welfare, but still very little is known about the relationship between photoperiod and circadian rhythm over the zootechnical performance, welfare, the immune system, and the intestinal microbiota of poultry. Thus, this review aims to gather the most recent studies on this subject and contribute to its better understanding.

\section{The intestinal microbiota of birds}

The gastrointestinal tract (GIT) of birds is composed of the oral cavity, esophagus, crop, proventricle, gizzard, duodenum, jejunum, ileum, cecum, colon, and cloaca. The GIT of birds is lower than that of mammals of the same size, but it houses a complex and functional microbiome composed mainly of bacteria and low levels of protozoa, fungi, yeasts, bacteriophages, and viruses, which interact with each other, with the host and with the food eaten by the host (Zhu et al., 2002). 
The intestinal microbiota is composed of commensal and pathogenic microorganisms representing a more extensive and smaller group, respectively (Yadav and Jha, 2019). Its composition varies along the GIT, with the formation of distinct communities, since it is affected by dietary nutrients, the level of oxygen, the immune response, and several substances produced and secreted that make up this microcosmos (Thompson and Applegate, 2005; Oviedo-Rondón et al., 2006; Yeoman et al., 2012; Waite and Taylor, 2014; 2015).

In the proventricle and gizzard, the low $\mathrm{pH}$ causes a decrease in the bacterial population, favoring lactic bacteria, such as Lactobacillus spp. In the duodenum, the intestinal microbiota is strongly influenced by digestive enzymes, high levels of oxygen, and bile salts, which may reduce the microbial concentration. However, in the distal portions of the small intestine and the large intestine, there is an increase in the abundance and diversity of microorganisms (Yadav and Jha, 2019). Apajalahti et al. (2004) demonstrated that ileum and cecum are the most favorable environments for bacterial growth, resulting in $10^{9}$ and $10^{11} \mathrm{CFU}$ per gram of content, respectively. In a more recent study, Borda-Molina et al. (2016) showed that the bacterial concentration gradually increases along with the intestinal segments, $10^{5}$ $\mathrm{CFU} / \mathrm{g}, 10^{7} \mathrm{CFU} / \mathrm{g}$, and $10^{12} \mathrm{CFU} / \mathrm{g}$ are found duodenum, ileum, and colon, respectively.

The intestinal microbiota of birds is composed of hundreds of bacterial species, which mainly belong to the phyla Firmicutes, Bacteroidetes, Proteobacteria, and Actinobacteria (Oakley et al., 2014; Clavijo and Flórez, 2018), which are divided into different microbial communities and which differ along the GIT as well (Yeoman et al., 2012; Yan et al., 2017). The small intestine is composed of gram-positive bacteria, such as Lactobacillus, Enterococcus, Turicibacter, Clostridium sensu stricto and Romboutsia (Kollarcikova et al., 2019), whereas the cecum is colonized by Lactobacillus, Enterococcus, coliforms, and yeasts (Savage, 1977; Gaskins, 2001). As for the 
bacterial variety and diversity, there is no consensus among researchers; Apajalahti et al. (2004) reported the existence of 640 species and 140 bacterial genera in the GIT of birds. Wei et al. (2013) found in their study a greater bacterial diversity, with 915 species and 117 genus. Furthermore, recently, Hieke et al. (2019) published the existence of 19 phyla, 89 families, and 118 different genus. Such variation in the intestinal microbiota found by researchers is normal, since the age of birds (Shaufi et al., 2015; Bae et al., 2017; Chen et al., 2019; Glendinning et al., 2019; Kollarcikova et al., 2019; Ocejo et al., 2019), genetics (Zhao et al., 2019), and genetics (Zhao et al., 2019) are the most important factors in the development of a microbiota, 2013; Meng et al., 2014), diet (Scott et al., 2013; Borda-Molina et al., 2016; Park et al., 2017; Ocejo et al., 2019), drug use (Ladirat et al., 2013), as well as environmental factors such as density and caloric stress (Zhang et al., 2017; Wang et al., 2018).

With the advent of omics sciences (genomics, transcriptomics, metagenomics, proteomics, among others), there has been significant progress in studies of the microbiome, favoring new species' discovery microorganisms (Borda-Molina et al., 2018; Shang et al., 2018), but there is still much to be discovered.

\subsection{Importance of the intestinal microbiota for birds}

The commensal microbiota has great importance for the life of birds since it is linked to the formation and development of intestinal morphological structures, maturation of the immune system (Lei et al., 2015), protection against intestinal pathogens, and the digestive process, producing and providing nutrients (Rinttilä and Apajalahti, 2013). For Oviedo-Rondón et al. (2006), the intestinal microbiota forms the intestinal mucosa's first defense mechanism against pathogenic bacteria. This mechanism is called Competitive Exclusion and it occurs due to the production of bacteriocins, 
occupation of binding sites, stimulation of the immune system, and competition for nutrients (Van der Waaij et al., 1971; Kelly et al., 2001).

Short-chain fatty acids (SCFAs), enzymes, amino acids, vitamins B and $\mathrm{K}$ are examples of nutrients produced by the intestinal microbiota through fermentative and secretory processes (Barnes, 1979; Savage, 1986; Ewing, 1994; Gaskins, 2001). The main SCFAs produced by commensal bacteria are acetic, propionic, butyric, capric and lactic (Van der Wielen et al., 2000; Snel et al., 2002, Hinton Jr. and Ingran, 2011).

The importance of the balance of the intestinal microbiota in abundance provides better intestinal health for poultry, with this, a more significant weight gain and less feed conversion is expected (Oviedo-Rondón and Hume, 2013).

\subsection{Formation of intestinal microbiota of birds}

It is believed that there is an inheritance from the maternal microbiota to its progeny, and there may be the transmission of microbiota during the process of egg formation in the oviduct (Ding et al., 2017). This was indeed shown by Lee et al. (2019) when proving the existence of 21 common genera between embryos and their mothers' oviducts.

Soon after birth, the chicks have a rudimentary microbiota, that is, the intestine is not yet adequately colonized. Intestinal colonization happens very quickly, reaching $10^{8}$ and $10^{10} \mathrm{CFU} / \mathrm{g}$ of intestinal content in the ileum and cecum, on the third day of life, respectively. The origin of the microorganisms is linked to the hatchery, the first consumed nutrients, and the external environment (Apajalahti et al., 2004; Kubasova et al., 2019). For this reason, the use of antibiotics in the first days of life should be avoided, as it promotes a negative effect on the formation of the intestinal microbiota and impairing the development of the immune system (Schokker et al., 2017). 
After the first week of life and the end of the colonization process, the following two weeks will be necessary for the intestinal microbiota to organize itself along with the intestinal development (Oakley et al., 2014; Shang et al., 2018; Johnson et al., 2018; Jurburg et al., 2019). Thus, bacterial communities diversify themselves according to age, sex, diet, breeding environment, heat stress, use of antibiotics, and the photoperiod (Knarreborg et al., 2002; Zhu et al., 2002; Lu et al., 2003; Zhao et al., 2013; Jha and Berrocoso, 2015; Wang et al., 2018; Carrasco et al. 2019; Hieke et al., 2019; Ngunjiri et al., 2019).

\subsection{Factors that promote dysbiosis in birds}

At certain times, the intestinal microbiota may be driven out from an equilibrium state (eubiosis). Pathogenic microbiota grows beyond normal at such times, causing problems to the host; this is called dysbiosis. Stresscausing factors, such as heat, favor the growth of pathogenic microbiota, promoting dysbiosis (Zhang et al., 2017). Rations with excess nutrients also favor the growth of pathogenic bacteria like Clostridium perfringens (Bedford, 1995; Apajalahti and Bedford, 1999; Brown et al., 2012; Chan et al., 2013), leading to dysbiosis (Round and Mazmanian, 2009; Weiss and Hennet, 2017) and as a consequence, inflammatory processes and decreased performance (Kogut et al., 2018). Dysbiosis negatively affects intestinal cells, making nutrient absorption difficult, supporting pathogenic bacteria to develop (Brown et al., 2012). The excess of protein and fat promotes the proliferation of the pathogenic microbiota in the cecum, with physiological retroperistalsis, the pathogenic microbiota returns to the ileum and jejunum, causing dysbiosis and even disease due to the production of endo and exotoxins (Yegani and Korver, 2008; Oviedo -Rondón, 2019). This problem is common in young birds when microbial communities have not yet stabilized (OviedoRondón, 2019). 


\section{Types of light programs in poultry production}

The light program can be done intermittently or continuously. The intermittent light program consists of dividing the light period (photoperiod) into two or more periods during a 24-hour cycle. The continuous light program makes only one interruption between the photoperiod and the dark period (Buyse et al., 1996; Kühn et al., 1996; Buys et al., 1998; Apeldoorn et al., 1999; Schwean-Lardner et al., 2007). In this way, the light program is directly related to the circadian rhythm, which in turn acts on the intestinal microbiota, as well as on several vital functions and the host's behavior (Hastings et al., 2003; Mohawk et al., 2012; Nobs et al., 2019), since the light stimuli will act on the suprachiasmatic nucleus of the central nervous system (Voigt et al., 2016). As a consequence, an intermittent light program, may harm the circadian rhythm, as it performs more than one light stimulus over 24 hours. Moreover, this differs partially from Oliveira and Lara (2016), who defined the light program as a management technique used in poultry rearing, which respects the birds' physiological conditions and welfare. Petek et al. (2019) and Pandey (2019) commented that the light program promotes the development of birds and prevents locomotor problems, such as tibial dyschondroplasia, and metabolic problems such as ascites and sudden death.

\subsection{Effects of the light program on poultry performance and welfare}

Several studies carried out between the 1950 and the 1980 revealed that the intermittent light program promotes more significant weight gain (Paulino, 1949; Barott and Pringle, 1951; Clegg and Sanford, 1951; Clegg and Sanford, 1951; Moore, 1957; Cherry and Barwick 1962; Wilson et al., 1984; Classen and Riddell, 1989). Between the 1990s and 2010s, new studies showed that the intermittent light program favored the growth and welfare 
of birds, as they found higher levels of growth hormone (Kühn et al., 1996), melatonin (Zheng et al., 2013), and a reduction in plasma levels of corticosteroids (Abbas et al., 2008). Slightly opposite with these findings, Olanrewaju et al. (2006) reported that both light programs can be highly efficient. However, in more recent studies in broilers (Averós and Estevez, 2018; Olanrewaju et al., 2018), they found no difference among the surveyed immune factors. Finally, Pandey (2019), analyzing the continuous light program, reported that a long photoperiod ( $>20$ hours/day) tends to present a more significant number of birds with leg problems and higher mortality due to sudden death. The lack of consistency of results among researchers on what is the best type of light program suggests that this topic be better studied.

\subsection{Effects of photoperious on poultry performance and welfare}

The duration of light or photoperiod is the second most crucial luminous aspect for the development of birds. Furthermore, it can be understood as the duration of the light period, in a 24-hour cycle (Lee, Park and Lee, 2017). In a study by Dixit, Singh, and Byrsat (2017), the authors attested that birds exposed to short photoperiods had more gonadotropin hormone inhibitors than birds exposed to long photoperiods. Pandey (2019) recommended that after the first seven days of life, the dark period should be interrupted and with a minimum of 4 hours. Thus, the photoperiod can

positively or negatively influence the performance of the birds. A study carried out by the genetic company Aviagen along with the Saskatchewan University of Canada, evaluated four different photoperiods (14, 17, 20, and 23 hours of light/day, after seven days of life) on the performance of broilers. It was possible to observe that feed conversion photoperiods with 14 and 17 hours of duration, had the best results. The lowest mortality rate was observed with 17 hours of light. 
On the other hand, the best weight gains were obtained with 17 and 20 hours of light. Thus, the work concluded that the idea is to work with a photoperiod between 17 and 20 hours of light, because 14 hours of light resulted in lower performance and 23 hours of light had the worst zootechnical indexes (Schwean-Lardner and Classen, 2010). As for bird welfare, Bayram and Özkan (2010) observed that long photoperiods decrease bird welfare. Averós and Estevez (2018) reported in their meta-analysis that a long photoperiod is only justified in a late slaughter situation, as there is an increase in food consumption and the birds' final weight. This result is in accordance with Classen and Riddell (1989) and Yang et al. (2015).

\subsection{Relationship between the photoperious and poultry intestinal microbiota}

The photoperiod has direct effects on the physiology and welfare of birds and may alter the intestinal microbiota. In a study by Wang et al. (2018), the authors evaluated the impact of three photoperiods (Control $=12.5$ hours of light; Longest photoperiod $=16$ hours of light; Shortest photoperiod $=8$ hours of light) on the intestinal microbiota of the bird's cecum. It was possible to observe that the photoperiod affected the specific abundance of the intestinal microbiota since, in the group with the largest photoperiod, there was a significant increase in the abundance of bacteria of the genus Aeriscardovia and Delftia, which are associated with the appearance of infectious diseases. In the group with the lowest photoperiod, an increase in the genus Lactococcus bacteria has been reported, which are related to the prevention of infectious diseases.

Few studies in the literature evaluated the relationship between the photoperiod and the intestinal microbiota of poultry. In one of these studies, Hieke et al. (2019) mention that chickens reared with long photoperiods (> 18 hours of light/day) can have detrimental effects on the normal circadian 
rhythm, causing changes in the intestinal microbiota and the establishment of stable communities. In this same study, the authors evaluated the effects of two photoperiods ( $\mathrm{NP}=12$ hours of light/day and $\mathrm{EP}=23$ hours of light/day) on the poultry intestinal microbiota. It was possible to observe a significant variation between them. Diversity estimates using the Mann-Whitney U tests were significantly higher for the NP group among different estimators (Chao, Simpson, Inverse Simpson), suggesting that the NP group supported high bacterial diversity. This pattern was consistent over the three weeks. Analysis of $a$ and $B$ diversities showed significant differences between the composition of the cecal microbiota in the studied groups. When analyzing the genera found in each group, it was possible to observe that the NP group had bacterial genera of primary fermentation of acetate and lactate, reducing cases of malabsorption and intestinal diseases (Engels et al., 2016). There was also an increase in the Lactobacillus spp genus, which promotes antimicrobial (Silva et al., 1987; Schillinger and Lucke, 1989) and probiotic activity (Patten and Laws, 2015; Marco et al., 2017). At the same time, the EP group had bacterial genera related to the onset of diseases, such as Alistipes, which has been directly associated to obesity in humans (Clarke et al., 2013) and Irritable Bowel Syndrome (Saulnier et al., 2011); and Blautia spp, which is related to chronic liver disease and directly related to Inflammatory Bowel Disease (Torres et al., 2016).

\subsection{Effects of the circadian rhythm on the immune system and the intestinal microbiota of birds}

The circadian rhythm controls several functions in the organisms. Fatrich diets contribute to the breakdown of homeostasis of the intestinal circadian rhythm (Zarrinpar et al., 2014; Leone et al., 2015), which may lead to the onset of inflammatory processes (Voigt et al., 2016), alteration of the microbiota (Mukherji et al., 2013; Leone et al., 2015), drop-in SCFAs 
production (Thaiss et al., 2014), and as a consequence, break the integrity of the intestinal barrier (Caricilli et al., 2014) and immune function (Malago, 2015). Changes in the microbiota are characterized by an increase in proinflammatory bacteria and a decrease in communities of anti-inflammatory bacteria producing butyrate (Voigt et al., 2016).

Under normal conditions, the immune system is regulated by circadian rhythmicity, and the breakdown of circadian homeostasis can have serious consequences (Logan and Sarkar, 2012; Cermakian et al., 2014; Curtis et al., 2014), such as increased susceptibility to Salmonella infection (Bellet et al., 2013), drop-in macrophage activity and a reduction in pro-inflammatory cytokines (Keller et al., 2009). Rosselot et al. (2016) reported that the circadian rhythm, the immune system, and the intestinal microbiota have a direct relationship among themselves, influencing each other, mainly in controlling infectious diseases such as salmonellosis.

Constant changes in the light supply will negatively impact the intestinal microbiota, as according to Thaiss et al. (2014), up to $20 \%$ of intestinal bacteria can vary in abundance and relative activity, including Lactobacillus reuteri, Dehalobacterium spp. and other species belonging to the orders, namely: Clostridiales, Lactobacillales, and Bacteroidales. In a study with murine rodents, Zarrinpar et al. (2014) reported that $17 \%$ of intestinal bacteria were cyclical, with variation in the relative abundance of bacterial genera, such as Bacteroidetes, Firmicutes, and Proteobacteria. More recently, Liang et al. (2015) reported that the relative taxonomic abundance of murine rodents was higher during the dark period when animals were more active.

Thus, the host's circadian rhythmicity can alter the intestinal microbiota's composition and activity through the control of endogenous conditions, such as the control of diet and feeding time. The contrary is also applicable, that is, the intestinal microbiota can also influence the host (Voigt et al., 2016). 
Studies with rats revealed that TLRs (Toll-like Receptors), present in the intestinal crypts of the small intestine, perform the function of recognizing foreign antigens of pathogenic bacteria, stimulating TLR4 to release a-defensin in response to bacterial lipopolysaccharides (LPS) (Ayabe et al., 2000; Abreu et al., 2005). However, with the reduction of the intestinal microbiota, there is also a reduction in the activity of TLRs, due to the absence of bacterial metabolites, such as LPS (Mukherji et al., 2013). The circadian rhythm regulates the daytime release of a -defensins in the small intestine, increasing the defenses against pathogenic bacteria, which can be ingested with the feed (Froy et al., 2005).

In addition to the immune system, several chemical groups and hormones undergo significant fluctuations, such as serotonin, ergothioneine, lysine, xylose, glucose, and isovalerate (Thaiss et al., 2016). Paulose et al. (2016) revealed that melatonin production and body temperature directly influence intestinal microbiome's oscillation. Thus, it is likely that the intestinal microbiota has endogenous circadian rhythms, which interact with the host's circadian rhythm via signaling molecules such as the bird hormones.

\section{Future perspectives}

The poultry industry moves towards antibiotic-free production and for this it is necessary to know and understand the factors that negatively affect the intestinal microbiota, reducing performance and economic losses, and contributing to animal welfare.

\section{Conclusions}

The various shown studies made it possible to understand a little more about the effects of circadian rhythm and the photoperiod on the development, 
welfare, immune system, intestinal microbiota of birds, and the relationship of such factors within the host.

Very long photoperiods ( $>20$ hours/day) can be detrimental to poultry development since they negatively impact the intestinal microbiota, the development, and the welfare of the birds. Intermittent light programs can deregulate birds' circadian rhythm, penalize the intestinal microbiota, promote zootechnical losses due to less production of SCFAs, and increase intestinal inflammatory processes, favoring the development of pathogenic bacteria such as Salmonella, since the immune system and the intestinal barrier will also be compromised. Increasing the productivity of poultry without compromising their welfare and with restricted use of antibiotics is the biggest challenge of today's poultry production, and for that, increasingly agribusinesses will need to better control the internal environment of the poultry, the fecal quality of the birds, and shortly analyze the intestinal microbiota of birds throughout the breeding period.

$* * *$

\section{Efeito do fotoperíodo sobre a microbiota intestinal e o ritmo circadiano, e sua influência sobre o desempenho, o sistema imune e o bem estar de frangos de corte}

Resumo: A microbiota intestinal de frangos ainda reserva uma grande quantidade de segredos e mistérios. Entretanto, se sabe que ela atua de forma direta sobre a saúde do hospedeiro, mas que também é influenciada por diversos fatores, dentre eles a luz. Devido à importância da produção mundial de aves, esta revisão de literatura teve o objetivo de abrigar os estudos mais recentes, que relacionam o fotoperíodo e o ritmo circadiano, com a microbiota intestinal, o desempenho zootécnico, o sistema imune e o bem-estar de frangos de corte. Descrevendo em uma única obra a existência de uma relação bilateral entre a microbiota intestinal, o sistema imune e seu hospedeiro, e que pode ser influenciada de modo direto, pelo manejo da luz.

Palavras-chave: Programa de luz, Eubiose, Disbiose, Saúde Intestinal, Frangos. 


\section{References}

ABBAS, A.O.; et al. The effects of photoperiod programs on broiler chicken performance and immune response. Int. J. Poult. Sci. v. 7, n. 7, p. 665-671, 2008. DOI: $10.3923 /$ ijps.2008.665.671.

ABREU, M.T.; FUKATA, M.; ARDITI, M. TLR signaling in the gut in health and disease. J Immunol., v. 174, n. 8, p. 4453-4460, 2005. DOI: $\underline{10.4049 / j i m m u n o l .174 .8 .4453}$

APAJALAHTI, J.H.; BEDFORD, M.R. Improve bird performance by feeding its microflora. World Poult., v. 15, n. 2, p. 20-23, 1999.

APAJALAHTI J.; KETTUNEN A.; GRAHAM H. Characteristics of the gastrointestinal microbial communities, with special reference to the chicken. Worlds Poult Sci Journal, v. 60, n. 2, p. 223-32, 2004. DOI: 10.1079/WPS200415.

APELDOORN, E.J.; et al. Effect of melatonin and lighting schedule on energy metabolism in broiler chickens. Poult. Sci., v. 78, n. 2, p. 223-229, 1999. DOI: 10.1093/ps/78.2.223.

AYABE, T.; et al. Secretion of microbicidal alphadefensins by intestinal Paneth cells in response to bacteria. Nat Immunol., v. 1, p. 113-118, 2000. DOI: 10.1038/77783.

AVERÓS, X.; ESTEVEZ, I. Meta-analysis of the effects of intensive rearing environments on the performance and welfare of broiler chickens. Poult. Sci., v. 97, n. 11, p. $3767-3785,2018$. DOI: $10.3382 /$ ps/pey243.

BAE, Y., KOO, B., LEE, S., MO, J., OH, K., MO, I. P. Bacterial diversity and its relationship to growth performance of broilers. Korean Journal Veterinary Research, v. 57, n. 3, p. 159-167, 2017. 
BARNES, E.M. The intestinal microflora of poultry and game birds during life and after storage. J Appl Microbiology, v. 46, n. 3, p. 407-19, 1979. DOI: 10.1111/j.1365-2672.1979.tb00838.x.

BAROTT, H.G.; PRINGLE, E. Effect of environment on growth and feed and water consumption of chickens The Effect of Light on early growth. J. Nutr., v. 45, n. 2, p. 265-274, 1951. DOI: $\underline{10.1093 / \mathrm{jn} / 45.2 .265 .}$

BAYRAM, A.S.; ÖZKAN, B. Effects of a 16-hour light, 8-hour dark lighting schedule on behavioral traits and performance in male broiler chickens. J. Appl. Poult. Res. v. 19, n. 3, p. 263-273, 2010. DOI: 10.3382/japr.2009-00026.

BEDFORD, M.R. Mechanism of action and potential environmental benefits from the use of feed enzymes. Anim. Feed Sci. Technol., v. 53, n. 2, p. 145-155, 1995. DOI: 10.1016/0377-8401(95)02018-U.

BELLET, M.M.; DERIU, E.; et al. Circadian clock regulates the host response to Salmonella. Proceedings of the National Academy of Sciences of the United States of America, v. 110, n. 24, p. 9897-9902, 2013. DOI: 10.1073/pnas.1120636110.

BORDA-MOLINA, D.; et al. Insights into broilers' gut microbiota fed with phosphorus, calcium, and phytase supplemented diets. Frontiers in Microbiology, v. 7, p. 2033, 2016. DOI: 10.3389/fmicb.2016.02033.

BORDA-MOLINA, D.; SEIFERT, J.; CAMARINHA-SILVA, A. Current perspectives of the chicken gastrointestinal tract and its microbiome. Comput. Struct. Biotechnol. J., v. 16, p. 131-139, 2018. https://doi.org/10.1016/j.csbj.2018.03.002

BROWN, K.; et al. Diet-induced dysbiosis of the intestinal microbiota and the effects on immunity and disease. Nutrients, v. 4, n. 8, p. 1095-1119, 2012. DOI: 10.3390/nu4081095. 
BUYS, N.; et al. Intermittent lighting reduces the incidence of ascites in broilers: an interaction with protein content of feed on performance and the endocrine system. Poult. Sci. v. 77, n. 1, p. 54-61, 1998. DOI: 10.1093/ps/77.1.54.

BUYSE, J.P.C.M.; et al. Effect of intermittent lighting, light intensity and source on the performance and welfare of broilers. World's Poult. Sci. J., v. 52, n. 2, p. 121130, 1996. DOI: 10.1079/WPS19960012.

CARICILLI, A.M.; CASTOLDI, A.; et al. Intestinal barrier: a gentlemen's agreement between microbiota and immunity. World Journal of Gastrointestinal Pathophysiology, v. 5, n. 1, p. 18-32, 2014. DOI: 10.4291/wjgp.v5.i1.18.

CARRASCO, J.M.D.; CASANOVA, N.A.; MIYAKAWA, M.E.F. Microbiota, gut health and chicken productivity: what is the connection? Review - Microorganisms, v. 7 , n. 10, p. 374, 2019. DOI: 10.3390/microorganisms 7100374 .

CERMAKIAN, N.; WESTFALL, S.; et al. Circadian clocks and inflammation: Reciprocal regulation and shared mediators. Archivum Immunologiae et Therapiae Experimentalis, v. 62, n. 4, p. 303-318, 2014. DOI: 10.1007/s00005014-0286-x.

CHAN, Y.K.; ESTAKI, M.; GIBSON, D.L. Clinical consequences of diet-induced dysbiosis. Ann. Nutr. Metab., v. 63, n. 2, p. 28-40, 2013. DOI: $10.1159 / 000354902$.

CHEN, W., TANG, S., JAHROMI, M. F., CANDYRINE, S. C., IDRUS, Z.; ABDULLAH, N., LIANG, J. B. Metagenomics analysis reveals significant modulation of cecal microbiota of broilers fed palm kernel expeller diets. Poultry Science, v. 98, n. 1, p. 56-68, 2019.

CLARKE, S.F.; et al. Targeting the microbiota to address diet-induced obesity: a time dependent challenge. Plos One, v. 8, n. 6, e65790, 2013. DOI: 10.1371/journal.pone.0065790. 
CLAVIJO, V.; FLÓREZ, M.J.V. The gastrointestinal microbiome and its association with the control of pathogens in broiler chicken production: A review. Poult. Sci., v. 97, n. 3, p. 1006-1021, 2018. DOI: 10.3382/ps/pex359.

CLEGG, R.; SANFORD, P. The Influence of intermittent periods of light and dark on the rate of growth of chicks. Poult. Sci., v. 30, n. 5, p. 760-762, 1951. DOI: 10.3382/ps.0300760.

CLASSEN, H.; RIDDELL, C. Photoperiodic effects on performance and leg abnormalities in broiler chickens. Poult. Sci., v. 68, n. 7, p. 873-879, 1989. DOI: 10.3382/ps.0680873.

CURTIS, A.M.; BELLET, M.M.; et al. Circadian clock proteins and immunity. Immunity, v. 40, n. 2, p. 178-186, 2014. DOI: 10.1016/j.immuni.2014.02.002.

DING, J.; DAI, R.; YANG, L.; et al. Inheritance and establishment of gut microbiota in chickens. Front Microbiol., v. 8, p. 1967, 2017. DOI: 10.3389/fmicb.2017.01967.

DIXIT, A.S.; SINGH, N.S.; BYRSAT, S. Role of GnIH in photoperiodic regulation of seasonal reproduction in the Eurasian tree sparrow. The Journal of Experimental Biology, v. 220, p. 3742-3750, 2017. DOI: 10.1242/jeb.164541.

ENGELS, C.; et al. The common gut microbe eubacterium hallii also contributes to intestinal propionate formation. Frontiers in Microbiology, v. 7, p. 713, 2016. DOI: $\underline{10.3389 / \text { fmicb.2016.00713. }}$.

EWING, W.N.; COLE, D.J. Micro-flora of the gastro-intestinal tract. The living gut: An introduction to micro-organisms in nutrition, p. 45-65, 1994.

FROY, O.; CHAPNIK, N.; MISKIN, R. Mouse intestinal cryptdins exhibit circadian oscillation. FASEB Journal, v. 19, n. 13, p. 1920-1922, 2005. DOI: 10.1096/fj.054216fje. 
GASKINS, H.R. Intestinal bacteria and their influence on swine growth. Swine Nutrition, v. 2, p. 585-608, 2001. DOI: 10.1201/9781420041842.

GLENDINNING, L., WATSON, K. A., WATSON, M. Development of the duodenal, ileal, jejunal and caecal microbiota in chickens. Animal Microbiome, v. 1, n. 1, p. 17, 2019.

HASTINGS, M.H.; REDDY, A.B.; et al. A clockwork web: circadian timing in brain and periphery, in health and disease. Nature Reviews. Neuroscience, v. 4, n. 8 , p. 649-661, 2003. DOI: 10.1038/nrn1177.

HIEKE, A.S.C.; HUBERT, S.M.; ATHREY, G. Circadian disruption and divergent microbiota acquisition under extended photoperiod regimens in chicken. PeerJ, v. 7, e6592, 2019. DOI: 10.7717/peerj.6592.

HINTON Jr, A., INGRAM, K. D. Use of the agar diffusion assay to evaluate bactericidal activity of formulations of alkaline salts of fatty acids against bacteria associated with poultry processing. Journal of Food Safety, v. 31, n. 3, p. 357-364, 2011.

HUTH, J.C.; ARCHER, G.S. Comparison of two LED light bulbs to an dimmable CFL and their effects on broiler chicken growth, stress, and fear. Poult. Sci., v. 94, n. 9, p. 2027-2036, 2015. DOI: 10.3382/ps/pev215.

JHA, R.; BERROCOSO, J.D. Dietary fiber utilization and its effects on physiological functions and gut health of swine. Animal, v. 9, n. 9, p. 1441-52, 2015. DOI: 10.1017/S1751731115000919.

JOHNSON, T.J.; et al. A consistent and predictable commercial broiler chicken bacterial microbiota in antibiotic-free production displays strong correlations with performance. Appl. Environ. Microbiol., v. 84, p. e00362-18, 2018. DOI: 10.1128/AEM.00362-18. 
JURBURG, S.D.; et al. Patterns of community assembly in the developing chicken microbiome reveal rapid primary succession. Microbiol. Open., v. 8, n. 9, e00821, 2019. DOI: $10.1002 / \mathrm{mbo3.821.}$

KELLER, M.; MAZUCH, J.; ABRAHAM, U.; et al. A circadian clock in macrophages controls inflammatory immune responses. Proc. Natl. Acad. Sci., v. 106, n. 50, p. 21407-21412, 2009. DOI: 10.1073/pnas.0906361106.

KELLY, D.; et al. Regulation of gut function and immunity. Gut Environment of Pigs. Nottingham, UK: Nottingham University Press, p. 113-31, 2001.

KNARREBORG, A.; et al. Effects of dietary fat source and subtherapeutic levels of antibiotic on the bacterial community in the ileum of broiler chickens at various ages. Appl Environ Microbiol, v. 68, n. 12, p. 5918-24, 2002. DOI: 10.1128/aem.68.12.5918-5924.2002.

KOGUT, M.H.; et al. Inflammatory phenotypes in the intestine of poultry: not all inflammation is created equal. Poult. Sci., v. 97, n. 7, p. 2339-2346, 2018. DOI: $10.3382 / \mathrm{ps} / \mathrm{pey} 087$.

KOllarCiKOVA, M., KUBASOVA, T., KARASOVA, D., CRHANOVA, M., CEJKOVA, D., SISAK, F., RYCHLIK, I. Use of 16S rRNA gene sequencing for prediction of new opportunistic pathogens in chicken ileal and cecal microbiota. Poultry Science, v. 98, n. 6, p. 2347-2353, 2019.

KÜHN, E.R.; et al. The use of intermittent lighting in broiler raising. 2. Effects on the Somatotrophic and Thyroid Axes and on Plasma Testosterone Levels. Poult. Sci. v. 75 , n. 5, p. 595-600, 1996. DOI: 10.3382/ps.0750595.

KUBASOVA, T.; et al. Contact with adult hen a_ects development of caecal microbiota in newly hatched chicks. PLoS One, v. 14, n. 3, e0212446, 2019. DOI: 10.1371/journal.pone.0212446. 
LADIRAT, S. E., SCHOLS, H. A., NAUTA, A., SCHOTERMAN, M. H. C., KEIJSER, B. J. F., MONTIJN, R. C., GRUPPEN, H., SCHUREN, F. H. J. High-throughput analysis of the impact of antibiotics on the human intestinal microbiota composition. Journal of Microbiology and Methods, v. 92, n. 3, p. 387-397, 2013.

LEE, C.H.; PARK, Y.J.; LEE, Y.D. Effects of photoperiod manipulation on gonadal activity of the damselfish, chromis notata. Development \& Reproduction, v. 21, n. 2, p. 223-228, 2017. DOI: 10.12717/DR.2017.21.2.223.

LEE, S.; et al. Characterization of microbial communities in the chicken oviduct and the origin of chicken embryo gut microbiota. Scientific Reports, v. 9, p. 6838, 2019. DOI: 10.1038/s41598-019-43280-w.

LEI, Y.M.; NAIR, L.; ALEGRE, M.L. The interplay between the intestinal microbiota and the immune system. Clin Res Hepatol Gastroenterol., v. 39, n. 1, p. 9-19, 2015. DOI: 10.1016/j.clinre.2014.10.008.

LEONE, V.; GIBBONS, S.M.; et al. Effects of diurnal variation of gut microbes and highfat feeding on host circadian clock function and metabolism. Cell Host \& Microbe, v. 17, n. 5, p. 681-689, 2015. DOI: 10.1016/j.chom.2015.03.006.

LEWIS, P.D.; MORRIS, T.R. Responses of domestic poultry to various light sources. World's Poult. Sci. J., v. 54, n. 1, p. 7-25, 1998. DOI: 10.1079/WPS19980002.

LIANG, X.; BUSHMAN, F.D.; FITZGERALD, G.A. Rhythmicity of the intestinal microbiota is regulated by gender and the host circadian clock. Proc Natl Acad Sci., v. 112, n. 33, p. 10479-10484, 2015. DOI: 10.1073/pnas.1501305112.

LOGAN, R.W.; SARKAR, D.K. Circadian nature of immune function. Molecular and Cellular Endocrinology, v. 349, n. 1, p. 82-90, 2012. DOI: 10.1016/j.mce.2011.06.039. 
LU, J.; et al. Diversity and succession of the intestinal bacterial community of the maturing broiler chicken. Appl Environ Microbiology, v. 69, n. 11, p. 6816-24, 2003. DOI: 10.1128/AEM.69.11.6816-6824.2003.

MALAGO, J.J. Contribution of microbiota to the intestinal physicochemical barrier. Beneficial Microbes, v. 6, n. 3, p. 295-311, 2015. DOI: 10.3920/BM2014.0041.

MARCO, M.L.; HEENEY, D.; BINDA, S.; CIFELLI, C.J.; et al. Health benefits of fermented foods: microbiota and beyond. Current Opinion Biotechnology, v. 44, p. 94-102, 2017. DOI: 10.1016/j.copbio.2016.11.010.

MENG, H., ZHANG, Y., ZHAO, L., ZHAO, W., HE, C., HONAKER, C. F., ZHAI, Z., SUN, Z., SIEGEL, P. B. Body weight selection affects quantitative genetic correlated responses in gut microbiota. PLoS One, v. 9, n. 3, p. e89862, 2014.

MOHAWK, J.A.; GREEN, C.B.; et al. Central and peripheral circadian clocks in mammals. Annual Review of Neuroscience, v. 35, p. 445-462, 2012. DOI: 10.1146/annurev-neuro-060909-153128.

MUKHERJI, A.; et al. Homeostasis in intestinal epithelium is orchestrated by the circadian clock and microbiota cues transduced by TLRs. Cell, v. 153, n. 4, p. 812827, 2013. DOI: 10.1016/j.cell.2013.04.020.

NGUNJIRI, J.M.; TAYLOR, K.J.M.; ABUNDO, M.C.; JANG, H.; et al. Farm stage, bird age, and body site dominantly a ect the quantity, taxonomic composition, and dynamics of respiratory and gut microbiota of commercial layer chickens. Appl. Environ. Microbiol., v. 85, p. e03137-18, 2019. DOI: 10.1128/AEM.03137-18.

NOBS, S.P.; TUGANBAEV, T.; ELINAV, E. Microbiome diurnal rhythmicity and its impact on host physiology and disease risk. Review, EMBO Reports, v. 20, n. 4, p. e47129, 2019. DOI: 10.15252/embr.201847129. 
OAKLEY, B.B.; et al. The chicken gastrointestinal microbiome. FEMS Microbiol. Lett., v. 360, n. 2, p. 100-112, 2014. DOI: 10.1111/1574-6968.12608.

OCEJO, M., OPORTO, B., Hurtado, A. 16S rRNA amplicon sequencing characterization of caecal microbiome composition of broilers and free-range slowgrowing chickens throughout their productive lifespan. Scientific Reports, v. 9, n. 1, p. 1-14, 2019.

OLANREWAJU, H.A.; et al. A review of lighting programs for broiler production. International Journal of Poultry Science, v. 5, n. 4, p. 301-308, 2006. DOI: 10.3923/ijps.2006.301.308.

OLANREWAJU, H. A.; et al. Effects of genetic strain and light intensity on blood physiological variables of broilers grown to heavy weights. Poult. Sci., v. 93, n. 4, p. 970-978, 2014. DOI: 10.3382/ps.2013-03613.

OLANREWAJU, H. A.; et al. Influence of light sources and photoperiod on growth performance, carcass characteristics, and health indices of broilers grown to heavy weights. Poult. Sci., v. 97, n. 4, p. 1109-1116, 2018. DOI: 10.3382/ps/pex426.

OLIVEIRA, R.G. de; LARA, L.J.C. Lighting programmes and its implications for broiler chickens. Worlds. Poult. Sci. J., v. 72, n. 4, p. 735-742, 2016. DOI: 10.1017/S0043933916000702.

OVIEDO-RONDÓN, E.O. Holistic view of intestinal health in poultry. Animal Feed Science and Technology, v. 250, p. 1-8, 2019. DOI: 10.1016/j.anifeedsci.2019.01.009

OVIEDO-RONDÓN, E.O.; HUME, M.E. Equilibrium in the gut ecosystem for productive healthy birds. In Proceedings of the Arkansas Nutrition Conference. Rogers, AR, USA, p. 1-18, September 4-5, 2013. 
OVIEDO-RONDÓN, E.O.; et al. Intestinal microbial ecology of broilers vaccinated and challenged with mixed Eimeria species and supplemented with essential oil blends. Poult Sci., v. 85, n. 5, p. 854-60, 2006. DOI: 10.1093/ps/85.5.854.

PANDEY, U. Effect of lighting in broiler production. Acta Scientific Agriculture, v. 3, n. 6 , p. 114-116, 2019.

PARK, S. H., PERROTTA, A., HANNING, I., DIAZ-SANCHEZ, S., PENDLETON, S., ALM, E., RICKE, S. C. Pasture flock chicken cecal microbiome responses to prebiotics and plum fiber feed amendments. Poultry Science, v. 96, n. 6, p. 18201830, 2017.

PATTEN, D.A.; LAWS, A.P. Lactobacillus-produced exopolysaccharides and their potential health benefits: a review. Beneficial Microbes, v. 6, n. 4, p. 457-471, 2015. DOI: $10.3920 / \mathrm{BM} 2014.0117$.

PAULINO, L. Effects of varying lengths of illumination on rate of growth and mortality of chicks. Philipp. Agric. v. 33, p. 63-70, 1949.

PAULOSE, J.K. et al. Human gut bacteria are sensitive to melatonin and express endogenous circadian rhythmicity. PLoS One, v. 11, n. 1, p. e0146643, 2016. DOI: 10.1371/journal.pone.0146643.

PETEK, M.G.; et al. Effects of different management factors on broiler performance and incidence of tibial dyschondroplasia. Br. Poult. Sci., v. 46, n. 1, p. 16-21, 2005. DOI: $10.1080 / 00071660400023821$.

PITTENDRIGH, C.S.; DAAN, S. A functional analysis of circadian pacemakers in nocturnal rodents. Journal of Comparative Physiology, v. 106, p. 333-355, 1976. DOI: $10.1007 / \mathrm{BF} 01417860$. 
RINTTILÄ, T.; APAJALAHTI, J. Intestinal microbiota and metabolites. Implications for broiler chicken health and performance. J Appl Poult Res., v. 22, n. 3, p. 647-58, 2013. DOI: 10.3382/japr.2013-00742.

ROSSELOT, A.E.; HONG, C.I.; MOORE, S.R. Rhythm and bugs: circadian clocks, gut microbiota, and enteric infections. Curr. Opin. Gastroenterol, v. 32, n. 1, p. 7 11, 2016. DOI: 10.1097/MOG.0000000000000227.

ROUND, J.L.; MAZMANIAN, S.K. The gut microbiota shapes intestinal immune responses during health and disease. Nat. Rev. Immunol., v. 9, n. 5, p. 313-323, 2009. DOI: $10.1038 /$ nri2515.

SAULNIER, D.M.; RIEHLE, K.; MISTRETTA, T.A.; DIAZ, M.A.; et al. Gastrointestinal microbiome signatures of pediatric patients with irritable bowel syndrome. Gastroenterology, v. 141, n. 5, p. 1782-1791, 2011. DOI: 10.1053/j.gastro.2011.06.072.

SAVAGE, D.C. Gastrointestinal microflora in mammalian nutrition. Annu Rev Nutr., v. 6, n. 1, p. 155-78, 1986. DOI: 10.1146/annurev.nu.06.070186.001103.

SAVAGE, D.C. Microbial ecology of the gastrointestinal tract. Annu Rev $\begin{array}{llllllll}\text { Microbiology, } & \text { v. } 31, \quad \text { n. } \quad 1, \quad \text { p. } 107-33, \quad 1977 . & \text { DOI: }\end{array}$ 10.1146/annurev.mi.31.100177.000543.

SCHILLINGER, U.; LUCKE, F.K. Antibacterial activity of Lactobacillus sake isolated from meat. Applied and Environmental Microbiology, v. 55, n. 8, p. 1901-1906, 1989. DOI: 10.1128/AEM.55.8.1901-1906.1989.

SCHOKKER, D.; et al. Perturbation of microbiota in one-day old broiler chickens with antibiotic for 24 hours negatively affects intestinal immune development. BMC Genomics, v. 18, n. 241, 2017. DOI: 10.1186/s12864-017-3625-6. 
SCHWEAN-LARDNER, K.; CLASSEN, H.; FANCHER, B. Increasing lighting program effects on production characteristics of mother broilers. Poult. Sci., v. 86, p. 165, 2007.

SCHWEAN-LARDNER, K.; CLASSEN, H. Programa de luz para frangos de corte. Aviagen, 2010.

SHAUFI, M. A. M., SIEO, C. C., CHONG, C. W., GAN, H. M., HO, Y. W. Deciphering chicken gut microbial dynamics based on high-throughput 16S rRNA metagenomics analyses. Gut Pathogens, v. 7, n. 1, p. 4, 2015.

SHANG, Y.; et al. Chicken Gut Microbiota: Importance and Detection Technology. Front. Vet. Sci., v. 5, p. 254, 2018. DOI: 10.3389/fvets.2018.00254.

SILVA, M.; et al. Antimicrobial substance from a human Lactobacillus strain. Antimicrobial Agents and Chemotherapy, v. 31, n. 8, p. 1231-1233, 1987. DOI: 10.1128/aac.31.8.1231.

SNEL, J.; et al. Dietary strategies to influence the gastrointestinal microflora of young animals, and its potential to improve intestinal health. Nutr Health Gastrointest tract, p. 37-69, 2002.

TÄHKÄMÖ, L.; PARTONEN, T.; PESONEN, A.K. Systematic review of light xposure impact on human circadian rhythm. Chronobiol. Int., v. 36, n. 2, p. 1-20, 2018.

THAISS, C.A.; et al. Microbiota diurnal rhythmicity programs host transcriptome oscillations. Cell, v. 167, n. 6, p. 1495-1510, 2016. DOI: 10.1016/j.cell.2016.11.003.

THAISS, C.A.; ZEEVI, D.; et al. Transkingdom control of microbiota diurnal oscillations promote metabolic homeostasis. Cell, v. 159, n. 3, p. 514-529, 2014. DOI: 10.1016/j.cell.2014.09.048. 
THOMPSON, K.; APPLEGATE, T.J. Nutrients, nutritional state and small intestinal microbiota. In: Nutrients, Nutritional State, and Small Intestinal Microbiota. Raleigh, NC, USA: 32nd Annual Carolina Poultry Nutrition Conference, Research Triangle Park, NC. Carolina Feed Industry Association/North Carolina State University, p. 28-37, 2005.

TORRES, J.; et al. The features of mucosa-associated microbiota in primary sclerosing cholangitis. Alimentary Pharmacology \& Therapeutics, v. 43, n. 7, p. 790-801, 2016. DOI: 10.1111/apt.13552.

VAN DER WAAIJ, D.; BERGHUIS-DE VRIES, J.M.; LEKKERKERK-VAN DER WEES, J.E. Colonization resistance of the digestive tract in conventional and antibiotictreated mice. Epidemiol Infect, v. 69, n. 3, p. 405-11, 1971. DOI: $10.1017 / \mathrm{s} 0022172400021653$.

VAN DER WIELEN, P.W.; et al. Role of volatile fatty acids in development of the cecal microflora in broiler chickens during growth. Appl Environ Microbiol., v. 66, n. 6, p. 2536-40, 2000. DOI: 10.1128/aem.66.6.2536-2540.2000.

VOIGT, R.M.; et al. Circadian rhythm and the gut microbiome. International Review of Neurobiology, v. 131, p. 193-205, 2016. DOI: 10.1016/bs.irn.2016.07.002.

WAITE, D.W.; TAYLOR, M.W. Characterizing the avian gut microbiota: membership, driving influences, and potential function. Frontiers in Microbiology, v. 5, p. 223, 2014. DOI: 10.3389/fmicb.2014.00223.

WAITE, D.W.; TAYLOR, M.W. Exploring the avian gut microbiota: current trends and future directions. Frontiers in Microbiology, v. 6, p. 673, 2015. DOI: 10.3389/fmicb.2015.00673. 
WALTON, J.C.; WEIL, Z.M.; NELSON, R.J. Influence of photoperiod on hormones, behavior, and immune function. Frontiers in Neuroendocrinology, v. 32, n. 3, p. 303-319, 2011. DOI: 10.1016/j.yfrne.2010.12.003.

WANG, J.; et al. 16S rRNA gene sequencing reveals effects of photoperiod on cecal microbiota of broiler roosters. PeerJ, v. 6, p. e4390, 2018. DOI: 10.7717/peerj.4390.

WANG, X. J., FENG, J. H., ZHANG, M. H., LI, X. M., MA, D. D., CHANG, S. S. Effects of high ambient temperature on the community structure and composition of ileal microbiome of broilers. Poultry Science, v. 97, n. 6, p. 2153-2158, 2018.

WEI, S.; MORRISON, M. YU, Z. Bacterial census of poultry intestinal microbiome. Poult Science, v. 92, n. 3, p. 671-83, 2013. DOI: 10.3382/ps.2012-02822.

WEISS, A.; HENNET, T. Mechanisms and consequences of intestinal dysbiosis. Cell. Mol. Life Sci., v. 74, p. 2959-2977, 2017. DOI: 10.1007/s00018-017-2509-x.

WESTLAND, S.; PAN, Q.; LEE, S. A review of the effects of colour and light on nonimage function in humans. Color. Technol. v. 133, n. 5, p. 349-361, 2017. DOI: $\underline{10.1080 / 07420528.2018 .1527773 .}$.

WILSON, J.; et al. Effects of light and feeding space on leg abnormalities in broilers. Poult. Sci. v. 63, n. 3, p. 565-567, 1984. DOI: 10.3382/ps.0630565.

YADAV, S.; JHA, R. Strategies to modulate the intestinal microbiota and their effects on nutrient utilization, performance, and health of poultry. Journal of Animal Science and Biotechnology, v. 10, n. 2, 2019. DOI: 10.1186/s40104-018$\underline{0310-9}$.

YAN, W.; et al. Gut metagenomic analysis reveals prominent roles of Lactobacillus and cecal microbiota in chicken feed efficiency. Sci. Rep., v. 7, n. 45308, 2017. DOI: 10.1038/srep45308. 
YANG, Y. F.; et al. Growth responses of broiler chickens to different periods of artificial light. J. Anim. Sci. v. 93, n. 2, p. 767-775, 2015. DOI: 10.2527/jas.20148096.

YEGANI, M.; KORVER, D.R. Factors affecting intestinal health in poultry. Poult. Sci., v. 87, n. 10, p. 2052-2063, 2008. DOI: 10.3382/ps.2008-00091.

YEOMAN, C.J.; et al. The microbiome of the chicken gastrointestinal tract. Anim Health Res Rev., v. 13, n. 1, p. 89-99, 2012. DOI: 10.1017/S1466252312000138.

ZHANG, C.; et al. Resveratrol alleviates heat stress-induced impairment of intestinal morphology, microflora, and barrier integrity in broilers. Poultry Science, v. 96, n. 12, p. 4325-4332, 2017.

ZHANG, P.; et al. Probiotic mixture ameliorates heat stress of laying hens by enhancing intestinal barrier function and improving gut microbiota. Italian Journal of Animal Science, v. 16, N. 2, p. 292-300, 2017. DOI: $\underline{10.1080 / 1828051 X .2016 .1264261}$

ZARRINPAR, A.; et al. Diet and feeding pattern affect the diurnal dynamics of the gut microbiome. Cell, v. 20, n. 6, p. 1006-1017, 2014. DOI: 10.1016/j.cmet.2014.11.008.

ZHAO, L.; et al. Quantitative genetic background of the host influences gut microbiomes in chickens. Sci. Rep., v. 3, n. 1163, 2013. DOI: 10.1038/srep01163.

ZHENG, L.; et al. Growth performance, antioxidant status, and nonspecific immunity in broilers under different lighting regimens. J. Appl. Poult. Res., v. 22, n. 4, p. 798-807, 2013. DOI: 10.3382/japr.2012-00713.

ZHU, X.Y.; et al. 16S rRNA-based analysis of microbiota from the cecum of broiler chickens. Appl Environ Microbiology, v. 68, n. 1, p. 124-37, 2002. DOI: 10.1128/AEM.68.1.124-137.2002 